ISSN 2078-6441. Вісник Львівського університету. Серія географічна. 2013. Випуск 42. С. 350-356. Visnyk of the Lviv University. Series Geography. 2013. Issue 42. P. 350-356.

$911.3: 615.838$

\author{
'ячесл в одоров ${ }^{1}$, лентин лійник ${ }^{2}$ \\ 1 зм їльський держ вний гум ніт рний університет, \\ вул. епін , 12, 68600, м. зм їл, кр їн \\ 2 деськ н иіон льн к демія х рчових технологій, \\ вул. н тн, 112, 65039, м. дес, кр їн
}

ро н лізов но соці льно-економічні передумови як один з чинників формув ння т стійкого розвитку туристично-рекре ційного господ рств деської обл. иявлено, які нег тивні тенденції розвитку обл сного регіону можуть ст ти к т ліз тором розвитку туристичнорекре ційної діяльності.

лючові слов : деськ обл., туристично-рекре ційн діяльність, соці льно-економічні чинники, депопуляція н селення, безробіття.

либок економічн криз , як охопил укр їнське суспільство, призвел до зн чного погіршення умов життєдіяльності н селення. ьогодні основними чинник ми, що зумовлюють несприятливі суспільні процеси, є від'ємний природний приріст, “соці льне" сирітство, збільшення н в нт ження н тих, хто пр цює, зі збереженням з ст рілих технологій, зн чне скорочення ф ктичних доходів н селення, розп д держ вної безкоштовної системи охорони здоров'я, зменшення кількості медичних лікув льних з кл дів, погіршення екологічної ситу ції, поширення інфекційних 3 хворюв нь тощо. йбільш болюче це вд рило по сільській місцевості.

ведені нег тивні тенденції розвитку кр їни об'єдн ємо в дві групи. о першої групи з числимо чинники, що зумовлені демотрудоресурсними проблем ми суспільств , до другої - чинники, що зумовлюють якість людського потенці лу. езумовно, вони дуже вз ємопов'яз ні т вз ємозумовлені.

к в рі нт пом'якшення цієї ситу ції можн розгляд ти розвиток туристичнорекре ційного господ рств . одного боку, це д сть змогу з діяти місцеві ресурси (як людські, т к і інфр структурні), з іншого, - н туризм т відпочинок в кр їні, що інтенсивно розвив ється, буде зн чний (у тому числі й внутрішній) попит. е стосується і деської обл., як вирізняється унік льним геогр фічним положенням, зн чною диференці цією дміністр тивних одиниць 3 рівнями соці льно-економічного розвитку т з безпеченості туристично-рекре ційними ресурс ми.

оловною особливістю геогр фічного положення дещини є іï приморське т прикордонне положення. он 3 йм є територію івнічно- хідного ричорномор'я гирл

ун ю до джибейського лим ну. сторичними б тьківщин ми основних етнічних меншин є держ ви, з якими регіон м є сухопутні т морські кордони. усідні держ ви ( уреччин , умунія, олг рія, олдов тощо) підтримують тісні зв'язки зі своїми ді спор ми бо етнічно близькими спільнот ми.

(C) одоров ., лійник ., 2013 
егіоном проходять тр си діючих і м йбутніх міжн родних тр нспортних коридорів ( ), зокрем № 7 - “ ун йський водний шлях” т кі ( інляндія) - лекс ндруполіс ( реція)”. ун й розгляд ють як одну з ключових л нок TRACECA - “ вроп - вк з - зія” т вро- зійського н фтотр нспортного коридор (“" ”). ерез регіон проходять л нки м йбутньої диної тр нспортної системи кр їн орноморського економічного співробітництв ( ). ижньому ун ї ктивізується тр нскордонне співробітництво, орг нізовують міжн родні поромні перепр ви, зрост є прикордонн торгівля, розробляють прогр ми міжн родного співробітництв .

дещин порівняно пог но з безпечен природними ресурс ми. е особливо помітно в ході н лізув ння н явних мінер льно-сировинних ресурсів. ут є незн чні з п си бурого вугілля (м. олгр д), н фти (с. улевч р тського р-ну), в пняку (с. л в ни рцизького р-ну), пісків (м. илкове т с. бо ілгород- ністровського р-ну) т м рмуру і доломіту (північніше від міст ілгород- ністровський) одноч с південно-з хідн ч стин обл сного регіону виділяється рекре ційним потенці лом (клім т, море, лікув льні грязі, мінер льні джерел , роп лим нів і моря), біологічними ресурс ми моря, лим нів, великих річок, високоцінними біосферними ресурс ми, що предст влені унік льними і своєрідними природними комплекс ми (пл вні, коси, пересипи), екосистем ми т біоценоз ми. се ж н йбільш зн чущими природними ресурс ми є земельні.

бл сть м є величезні водні ресурси, які є винятковими для степової зони. они предст влені двом великими річк ми ( ун й, ністер), ридун йськими озер ми, підземними вод ми різної якості. кремо виділимо приморські лим ни-озер . йбільшими серед них є ністровський, уд цький, урн с, лібей, г ни, сик, уяльник, джибей, илігул. ля з доволення рекре ційних потреб н селення обмежен можливість використ ння тільки ресурсів лим ну сик. е зумовлено нег тивним результ том його опріснення дун йською водою, яке проведене 1978 р. зн чимо, що, незв ж ючи н все це, ун й- ністерське межиріччя н лежить до території з вкр й обмеженими з п с ми доброякісної питної води.

ількість н селення деської обл. 3 ст ном н 1 січня 2012 р. ст новил 2 388,3 тис. осіб, що н 9,4 \% (247 тис. осіб) менше, ніж у 1991 р. ост нній рік, що передув в цій д ті, людність зменшил ся н 0,4 тис. осіб. 1991 р. в обл сному регіоні 3 г лом простежується депопуляція н селення. ерез чотири роки цей процес поч в перев ж ти в межиріччі ун ю т ністр . прикінці 2010-х років н йгірші геодемогр фічні процеси знову розпоч лися в північних р йон х. прикл д, у 2011 р. п’ять н йбільших к т строфічних пок зників були вл стиві н ньївському $(-7,5 \%$ \%), лтському $(-8,2)$, одимському $(-8,1)$, отовському $(-3,9)$ т $\quad$ вр нському $(-4,8 \%$ р $)$ йон м. р ктично т к ж ситу ція з фіксов н із рік до того [1].

диним їхнім ре льним конкурентом у цьому нег тивному рейтингу є друге 3 людністю місто обл сного регіону - зм їл $(-3,1 \%$ ). йбільше місто кр їнського ридун в'я з 1991 по 2012 р. втр тило 22,6\% н селення. е є н слідком зн чного погіршення умов життєдіяльності. р ктично всі підприємств , що визн ч ли обличчя не тільки міст, й усього регіону (целюлозно-к ртонний, консервний комбін ти тощо), пр ктично зникли з економічної к рти. істоутворюв льні господ рські суб'єкти зм їльський морський торговельний порт т ун йське річкове п ропл вство зн чно скоротили свої пок зники. 
тр ти зм їл можемо порівняти тільки з втр т ми основного економічного центру периферійної ч стини ун й- ністерського межиріччя - міст рциз. ут нег тивні тенденції руху н селення зн чно зумовлені ліквід цією н йбільшого в кр їні військового еродрому.

бсолютному вир женні зн чніше зменшення кількості н селення було х р ктерне тільки для м. дес . н логічний період обл сний центр утр тив 92,5 тис. осіб, що ст новить 8,4\% його н селення. ині місто $є$ н гр ні втр ти ст тусу міст мільйонер .

т строфічн соці льно-економічн т демогр фічн ситу ція в зм їлі підтверджен й особливістю мігр ційного приросту н селення. істо ст більно втр ч $е$ щорічно близько 10 осіб н кожну 1000 н селення. е н йбільший від'ємний пок зник в обл сті. кі процеси ст влять під пит ння м йбутнє другого з людністю міст не тільки деської обл., центру ун йського портово-промислового комплексу, й усього кр їнського ридун в'я.

сторично південно-з хідн ч стин обл сного регіону ( кр їнське ридун в'я, ун й- ністерське межиріччя) упродовж зн чного періоду виділял ся н йліпшими геодемогр фічними пок зник ми. е було зумовлене високою н роджув ністю в середовищі етнон ціон льних груп. елик родин полегшув л обробку земельних н ділів. кщо до 1994 р. всі основні етнон ціон льні меншини регіону, які прожив ли головно в сільській місцевості, м ли природний приріст н селення, то після 1994 р. тільки в г г узьких поселеннях цей пок зник колив ється близько нуля.

т тево-віков структур є в жливою х р ктеристикою н селення. уч сн ст тевовіков структур н селення формується під впливом б г тьох чинників, головними 3 яких є демогр фічний, економічний т соці льний. деській обл. кількість жінок помітно перевищує чоловіче н селення, т к ситу ція зумовлен більшою трив лістю життя жінок. молодших вікових груп х перев ж ють хлопчики, оскільки їх н роджується трохи більше. н ступних вікових груп х співвідношення хлопчики-дівч т поступово вирівнюється вн слідок дещо більшої смертності чоловічого н селення.

ст рших вікових груп х різко перев ж $є$ жіноче н селення.

ормув ння нового типу демогр фічної поведінки серед молоді в кризовій ситу ції м є винятково в жливе зн чення. ез розробки і впров дження в життя економічних, юридичних, психологічних т інших з ходів, спрямов них н тр нсформ цію демогр фічної ситу ції неможливо докорінно змінити х р ктер демогр фічних процесів.

н ціон льним скл дом деськ обл. помітно вирізняється серед інших регіонів

кр їни. іï меж х прожив ють пон д 130 н ціон льностей і н родностей. ричому особи некорінних етносів ст новлять пон д $37 \%$ н селення обл сті, тоді як з г лом по кр їні цей пок зник - 26,4\%. сновними етнон ціон льними груп ми є укр їнці, росіяни, болг ри, молд в ни, г г узи, євреї, білоруси, вірмени тощо (н ведені в порядку зменшення кількості).

івденно-з хідн ч стин дещини р зом 3 к рп ттям вирізняються н йбільш строк тою етнічною структурою н селення. ут історично скл лися ре ли комп ктного розселення н ціон льних меншин - болг р, росіян, молд в н, г г узів. межиріччі другою з кількістю групою після укр їнців є болг ри. ело овтневе олгр дського р-ну - єдине в кр їні, у якому лб нці ст новлять третину мешк нців.

центр льній ч стині регіону т кож мешк є більше сотні спільнот, які розселені в поліетнічному середовищі. обл сному центрі мешк є більшість євреїв. північних p йон х укр їнці ст новлять пон д $80 \%$ н селення. ільки молдов ни розселені (як і н 
південному з ході) уздовж держ вного кордону зі своєю історичною 6 тьківщиною т поблизу колишньої столиці олд вської

безпеченість трудовими ресурс ми головно визн чен співвідношенням основних вікових груп н селення - допр цезд тного, пр цезд тного т післяпр цезд тного віку. продовж ост нніх двох десятиліть у скл ді н селення обл сті зн чно зменшил сь ч стк молодших вікових груп і, відповідно, збільшується ч стк ст рших людей [3]. дещин м є поліцентричний приморсько-ф с дний тип територі льної структури господ рств , основними сектор ми якого є зовнішньоекономічн діяльність, морегоспод рський, м шинобудівний, тр нспортний, рекре ційний і гропромисловий комплекси. ч сів дянського оюзу основн ч стин н селення т господ рств обл сного регіону концентрув лися в меж х двох портово-промислових комплексів ( деського т

ун йського). ині простежуються стійкі тенденції до збільшення н гром дження н селення в меж х деської промислової гломер ції.

деській обл. н йбільшим пріоритетом є розвиток г лузей морегоспод рського і тр нспортного комплексу (міжн родного тр нзиту, зовнішньоторговельного, морепромислового циклів). вершення будівництв глибоководного суднового ходу “ ун й- орне море” зн чно поліпшить тр нспортно-геогр фічне положення т підвищить роль кр їнського ридун в'я в системі міжн родних тр нспортнокомунік ційних зв'язків портів ун йського регіону вропи.

береговій зоні, що виділяється зн чним рекре ційно- нтропогенним н в нт женням н н вколишне середовище, концентруються головно портово-промислові ( дес , ллічівськ, жне, ені, зм їл, ілія, сть- ун йський, ілгород- ністровський), промислові ( олгр д, т рбун ри) центри i курортно-рекре ційні ( деський,

тоцько- ергієвський, т рбун рський) р йони. дн к і в приморській смузі курортно-рекре ційних зон інтенсивно розвив ється сільськогоспод рське виробництво. ут основними господ рськими суб'єкт ми є рибо гр рні підприємств .

ч сів дянського оюзу єдиним промисловим центром периферійної ч стини межиріччя ун ю т ністр з порівняно стійкою зоною економічного тяжіння було місто рциз. игідне тр нспортно-геогр фічне положення нівельов не низьким рівнем розвитку тр нспортної інфр структури в центр льній ч стині регіону. івнічні $\mathrm{p}$ йони деської обл. не можуть конкурув ти з центр льними т південно-з хідними р йон ми 3 економічним потенці лом т ресурсною б зою розвитку туристично-рекре ційного господ рств. сновними економічними центр ми є великий тр нспортний вузол, місто обл сного підпорядкув ння отовськ т колишній дміністр тивний центр олд вської місто лт . озселення н селення перев жно в м лих сільських поселеннях зробило цей субрегіон дещини тр диційно депресивним.

ісцем, де з н йбільшою вірогідністю люди можуть зн йти роботу, $є$ дес . $3 н$ чимо, що сюди в пошук х з робітку з'їждж ються мешк нці не тільки обл сного регіону, й усього ричорномор'я. ому с ме мігр ційне с льдо визн ч $є$ позитивну дин міку кількості н селення обл сного центру т сусідніх $\mathrm{p}$ йонів. зн чимо, що в ост нні п'ять-сім років пр ктично нівелюється роль вікової структури т освітньокв ліфік ційного рівня н селення. ільшість трудових мігр нтів-чоловіків ст ють різноробочими т пр цюють головно н будівництві. інки, які не м ють конкурентоспроможної в суч сних умов х спеці льності, пр цевл штовуються н сезонні роботи (прополюв ння виногр дників у ілгород- ністровському р-ні т цукрових буряків у північних $\mathrm{p}$ йон $\mathrm{x}$ дещини). редст вники обох ст тей після з вершення н вч ль- 
ного з кл ду перев жно не поверт ються до рідного поселення. ільшість 3 них пр цевл штовується з спеці льністю, як не м є нічого спільного з н бутим ф хом.

ільське господ рство тр диційно є провідним сектором економіки деської обл., який $з$ обсяг ми виробництв посід є третє місце, 3 з йнятим н селенням - перше. езв ж ючи н зн чне скорочення з йнятості н селення в господ рстві регіону, т к в гом роль цієї г лузі зберегл ся. ост нні дв десятиліття докорінно змінилося співвідношення ч сток сільськогоспод рських підприємств і прив тних господ рств н селення. 1990 р. сільськогоспод рські підприємств втричі перевищув ли 3 обсяг ми виробництв прив тні господ рств н селення. 1994 р. вони пр ктично зрівнялися, 32000 р. прив тні господ рств н селення 3 обсяг ми сільськогоспод рського виробництв вже вийшли вперед. ровідними г лузями рослинництв в обл сті є зернове господ рство, вирощув ння технічних культур - соняшнику (повсюдно) т цукрового буряку (у північних $\mathrm{p}$ йон х), овочівництво, виногр д рство т с дівництво [4].

ередня з робітн пл т в деській обл сті в 2011 р. ст новил близько 2,4 тис. грн. ільше від цієї суми в середньому отримув ли мешк нці міст дес, ллічівськ, отовськ т жне, омінтернівського т відіопольського дміністр тивних р йонів. он д 2,0 тис. грн. отримув ли т кож у поселеннях ілгород- ністровської міської р ди т місті зм їл. к не п р докс льно, одн к н йнижчу з робітну пл ту отримув ли в деяких р йон х ( рцизький, зм їльський, рутинський i т рбун рський р йони) ун й- ністровського межиріччя т в м. еплод р. обто існує диспропорція між економічним потенці лом субрегіонів дещини т рівнями з робітної пл ти.

фіційний рівень безробіття в регіоні порівняно невисокий - близько $1 \%$. дн к 3 зн чимо, що, згідно з офіційними ст тистичними д ними, з період з кінця 2005 р. по кінець 2011 р. рівень безробіття зменшився вдвічі. міст х обл сного підпорядкув ння цей пок зник зн чно менший, ніж з г лом по дещині. роте прихов не безробіття т неповн 3 йнятість $з$ чіп ють більшу ч стину н селення і є гострою соці льною проблемою. цьому тлі н йбільш н ближеним до ре льних пок зників $є$ рівень з реєстров ного безробіття в р сноокнянському т вр нському р йон х. ільки тут ці пок зники пон д 4 т $5 \%$, відповідно. Зн чимо, що $з$ оцінкою експертів прихов не безробіття в сільської місцевості ст новить пон д $30 \%$. оловними н прям ми ії подол ння є пріоритетний розвиток пр цемістких г лузей гропромислового комплексу, н рощув ння вл сної переробки сільськогоспод рської продукції в сільськогоспод рських підприємств х і дом шніх господ рств х. е льний добробут н селення, проте, з безпечений діяльністю кв ліфіков ної робочої сили, зокрем , у річковому тр нспорті, суднобудув нні, судноремонті, в інших г лузях м шино- т прил добудув ння.

тже, викон не дослідження д є змогу зробити деякі висновки т д ти рекоменд ції, що відобр ж ють соці льно-економічні передумови розвитку туристичнорекре ційного господ рств деської обл.:

1) дещин - один 3 н йбільш економічно розвинених регіонів кр їни, у якому туристично-рекре ційне господ рство вже $є$ г луззю спеці ліз ції. ут скл лися унік льні соці льно-економічні передумови для под льшого інтенсивного розвитку цієї г лузі господ рського комплексу;

2) про перспективність сфери туризму т рекре ції т кож свідч ть порівняно прогресивніш віков структур й к т строфічний рівень прихов ного (ф ктичного) безробіття в сільській місцевості. озвиток туристично-рекре ційного господ рств допоможе вирішити деякі проблеми сільської місцевості, головною з яких є з йнятість; 
3) поліетнічний скл д сільського н селення (н с мперед ун й- ністерського межиріччя), перев ж ння с моз йнятості т низьк $з$ робітн пл т в сільській місцевості м ють н д ти поштовх для розвитку сільського зеленого туризму, який не потребуе зн чних к піт ловкл день для поч тку вл сного бізнесу в цій ц рині;

4) незв ж ючи н н явні соці льно-економічні передумови й унік льні рекре ційні ресурси для розвитку б г тьох н прямів, індустрію туризму г льмує відсутність інфр структури.

1. іст т р йони деської обл сті з 2011 рік: т тистичний збірник / ерж вн служб ст тистики кр їни оловне упр вління ст тистики в деській обл сті; 3 ред. . . опилової. - дес : стропринт, 2012.-291 с.

2. деськ обл сть: еогр фічний тл с: оя м л тьківщин / ідп. ред. . . огурельськ . - . : п , 2002. -20 с.

3. деський регіон : передумови формув ння, структур т територі льн орг ніз ція господ рств : [н вч. посібник] / вт. колектив: . . опчієв [керівник], . . ондр тюк, . . ворськ [т ін.]. - дес : стропринт, 2012.-336 с.

4. деський регіон: природ, н селення, господ рство : [н вч. посібник] / . . опчієв, . . ондр тюк, . . олос [т ін.]; 3 з г. ред. . . опчієв . дес : стропринт, 2003.-184 с.

m ття: н дійшл до ред кцї̈ 08.08.2013

доопр иьов н 23.08 .2013

прийнят до друку 10.10.2013

\title{
SOCIO-ECONOMIC BACKGROUND OF TOURISM IN ODESSA REGION
}

\author{
Vyacheslav Todorov $^{1}$, Valentyna Oleynyk ${ }^{2}$ \\ ${ }^{1}$ Izmail State Liberal Arts University, \\ Repin Str., 12, UA - 68600 Izmail, Ukraine \\ ${ }^{2}$ Odessa National Academy of Food Technologies, \\ Kanatnaya Str., 112, UA - 65039 Odesa, Ukraine
}

Socio-economic conditions as a factor in the formation and development of sustainable tourism and recreation economy of Odessa region were analyzed. Negative trends in the regional area, what can become a catalyst for the development of tourism and recreational activities, were revealed.

Key words: Odessa region, tourism and recreation activities, socio-economic factors, depopulation, unemployment. 


\author{
ячесл в одоров ${ }^{1}$, лентин лейник ${ }^{2}$ \\ 1 зм ильский госуд рственный гум нит рный университет, \\ ул. епин , 12, 68600, г. зм ил, кр ин \\ 2 десск ян иион льн я к демия пищевых технологий, \\ ул. н тн я, 112, 65039, г. десс, кр ин
}

ро н лизиров но соци льно-экономические предпосылки к к один из ф кторов формиров ния и устойчивого р звития туристическо-рекре ционного хозяйств десской обл. ыявлено, к кие нег тивные тенденции р звития обл стного регион могут ст ть к т лиз тором $\mathrm{p}$ звития туристическо-рекре ционной деятельности.

лючевые слов : десск я обл., туристическо-рекре ционн я деятельность, соци льноэкономические ф кторы, депопуляция н селения, безр ботиц . 